\title{
Extension of the geographic distribution of Plecturocebus baptista (Pitheciidae, Primates) and a possible hybrid zone with Plecturocebus hoffmannsi: evolutionary and conservation implications
}

\author{
Alessandro ROCHA*®, Adrian P.A. BARNETT, Wilson R. SPIRONELLO \\ Instituto Nacional de Pesquisas da Amazônia (INPA), Grupo de Pesquisa de Mamíferos Amazônicos, Av. André Araújo, 2936, Manaus, Amazonas, Brazil \\ * Corresponding author: alessandrorocha.eco@gmail.com; https://orcid.org/0000-0001-7433-4933
}

\begin{abstract}
Titi monkeys (family Pitheciidae) are Neotropical primates highly diversified in morphology, ecology and genetics, with a wide geographic distribution, including the Amazon, Atlantic Forest, Cerrado, Pantanal and Caatinga. This diversity, together with knowledge gaps, generates uncertainties in titi monkey taxonomy and distribution. An example is Plecturocebus baptista, with only 14 occurrence records and an ill-defined distribution based on untested geographical barriers. Here, we report the occurrence of this species at a new locality outside its known range, across the Paraná-Urariá River, which was considered a distributional limit for the species. The new record implies an overlap of P. baptista with the range of $P$. hoffmannsi. We document the sighting of an apparent hybrid animal. Our observations suggest that i) the distribution of $P$. baptista needs to be reviewed, and ii) the evolutionary relationships between $P$. baptista and $P$. hoffmannsi may be more complex than previously assumed. Since both species share contiguous areas of potential hybridization, we question whether the two species arose via allopatric speciation.
\end{abstract}

KEYWORDS: biogeography, titi monkeys, Amazon Forest, hybridization

\section{Extensão da distribuição geográfica de Plecturocebus baptista (Pitheciidae, Primates) e uma possível zona híbrida com Plecturocebus hoffmannsi: implicações evolutivas e de conservação}

\section{RESUMO}

Macacos zogue-zogue (família Pitheciidae) são primatas neotropicais altamente diversificados em morfologia, ecologia e genética, com distribuição geográfica abrangente, incluindo a Floresta Amazônica, Mata Atlântica, Cerrado, Pantanal e a Caatinga. Essa diversificação, juntamente com lacunas de conhecimento, gera incertezas na taxonomia e distribuição das espécies. Um exemplo é Plecturocebus baptista, com apenas 14 registros de ocorrência e distribuição indefinida, baseada em barreiras geográficas não testadas. Aqui nós relatamos a ocorrência da espécie em uma nova localidade, fora de sua área conhecida de distribuição, que transpóe uma suposta barreira geográfica, o Rio Paraná-Urariá. O novo registro de P. baptista se sobrepóe à distribuição de $P$. hoffmannsi e, neste contexto, observamos um indivíduo aparentemente híbrido entre as duas espécies. Nossas observaçóes sugerem que i) a distribuição de $P$. baptista necessita ser revisada, e ii) a relação evolutiva entre $P$. baptista e $P$. hoffmannsi pode ser mais complexa do que se pensava. Como ambas espécies compartilham áreas contínuas de potencial hibridização, questionamos se as duas espécies resultaram de especiação alopátrica.

PALAVRAS-CHAVE: biogeografia, zogue-zogue, Floresta Amazônica, hibridização

Until recently, Neotropical primates of the family Pitheciidae, sub-family Callicebinae, popularly known as titis, all belonged to the genus Callicebus, Thomas 1903 . However, a revision by Byrne et al. (2016) divided this genus into three. Accordingly, there are now two genera in Amazonia (Cheracebus and Plecturocebus), and one occurring in the Atlantic Forest, Cerrado, Pantanal, and Caatinga biomes (Callicebus). Titi species are rarely sympatric and, in concordance with a widely agreed upon model (Ayres and Clutton-Brock 1992), are historically considered to be separated by discrete geographic barriers, such as rivers (Roosmalen et al. 2002). Collectively, the titis are the most specious group of Neotropical primates, with 35 known species (Byrne et al. 2016; Boubli et al. 2019). The large number of species, the remote areas of occurrence, 
poor representation in museum collections, combined with frequently complex intra- and inter-population variation (Serrano-Villavicencio et al. 2017), have led to a complex taxonomic history for this group (Hershkovitz 1990; Roosmalen et al. 2002), and new species continue to be described (Boubli et al. 2019). Therefore, it is essential to have well-defined geographical and taxonomic bases for effective conservation in this primate group (Carneiro et al. 2018).

Many titi species are poorly known both ecologically and biogeographically. Among these is Plecturocebus baptista (Lönnberg 1939), for which only fourteen records exist, all from the Brazilian Amazon: twelve visual sightings, four by Roosmalen et al. (2002) on the Uirá-Curupá River (Amazonas state), and eight by Printes et al. (2018) on the Tapajós River (Pará). In addition, there are museum skins of specimens collected at Lago Baptista $\left(03^{\circ} 18^{\prime} \mathrm{S}, 58^{\circ} 15^{\prime} \mathrm{W}\right)$ and Lago Tapaiúna $\left(03^{\circ} 23^{\prime} \mathrm{S}, 58^{\circ} 18^{\prime} \mathrm{W}\right)$, along the Amazonas River (Gualda-Barros 2012; Hershkovitz 1990). Dedicated field studies on P. baptista have yet to occur.

Our objective was (i) to report the presence of $P$. batista at a new locality, (ii) to highlight the existence of an area of sympatry between $P$. baptista and $P$. hoffmannsi (Thomas 1908), and (iii) to discuss the implications for the evolution and conservation of the two species.

Field observations were made in November and December 2014 and January 2015, during field transect surveys in the municipality of Maués, Amazonas state (Brazil), between the Maués-Açu and Maués-Mirim rivers, at two sites $2.5 \mathrm{~km}$ apart near the urban area of Maués city (Figure 1). Both sites are secondary forest areas under continuing human impact. The first site (Site 1) is close to rural human habitations, and the second site (Site 2) is on a transect in the forest near guaraná (Paullinia cupana Kunth) and rosewood (Aniba roseodora Ducke) plantations.

Titis were sighted on three occasions, totalling five individuals. The first sighting was of a group of three adult P. baptista, foraging at a height of $1.5 \mathrm{~m}$ above the ground at Site $1\left(3^{\circ} 23.704^{\prime} \mathrm{S}, 57^{\circ} 41.780^{\prime} \mathrm{W}\right)$. The second was of a single P. hoffmannsi individual, some $2 \mathrm{~m}$ from the ground at Site 2 $\left(3^{\circ} 24.348^{\prime} \mathrm{S}, 57^{\circ} 42.403^{\prime} \mathrm{W}\right)$. The third sighting was of a single individual resting at the edge of the forest, at a height of $3 \mathrm{~m}$, some $400 \mathrm{~m}$ from Site 1 . The latter animal had an appearance intermediate in colour pattern between P. baptista and $P$.
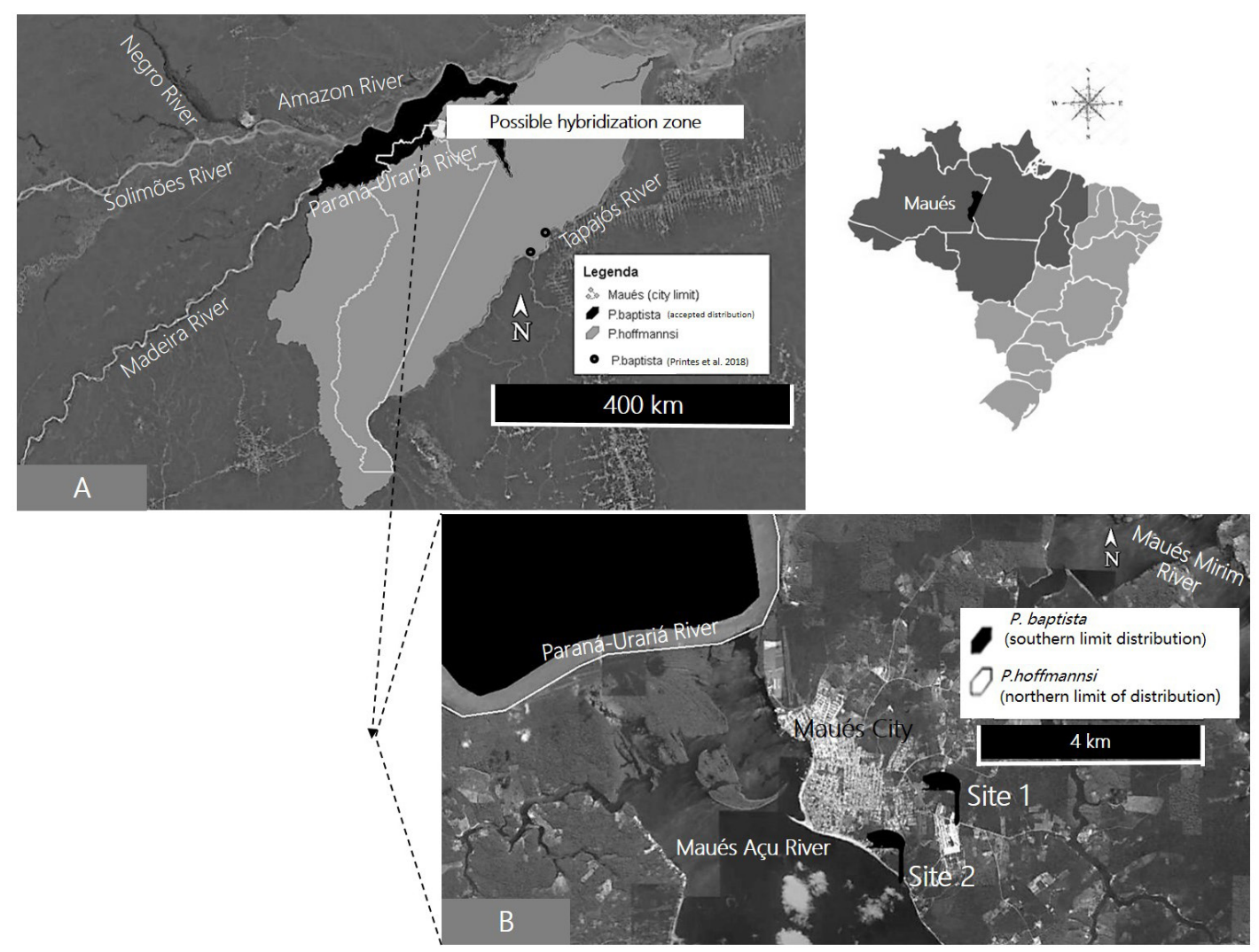

Figure 1. A - Known geographical range of Plecturocebus baptista, in black (Veiga 2008a) and Plecturocebus hoffmannsi, in gray (Veiga 2008b); indicating the potential hybridization zone in Maués, Amazonas state, Brazil; the map shows the location of the municipality of Maués in Brazil. B - Location of the two survey sites near the city of Maués, between the Maués-Açu and Maués-Mirim rivers, and the Paraná-Urariá River to the north. The historical distribution of $P$. baptista was bounded by the Paraná-Urariá River. At site 1, we found a hybrid of Plecturocebus (P. hoffmannsi x P. baptista) and a group of Plecturocebus baptista. At site 2 we observed a group of Plecturocebus hoffmannsi. 
hoffmannsi, with crown, forehead, dorsum, flanks, hand, feet, outer limbs and tail exhibiting a blackish color; reddish-yellow sideburns and inner limbs; and dark reddish-brown chest, neck and belly (Figure 2). All sighting locations lie within the known distribution range of $P$. hoffmannsi (Veiga 2008b). The external appearance of P. baptista and $P$. hoffmannsi is distinct, and both species can be differentiated in the field by a series of pelage color pattern characteristics (Table 1). Although the observation is suggestive of a hybrid, molecular analyses would be necessary to confirm hybridization (Boubli et al. 2018).

The new P. baptista records show that the species is sympatric, not allopatric, with $P$. hoffmannsi. Roosmalen et al. (2002) proposed that some titi species could also be related, parapatric, and separated by an evolutionary process (possibly chromosomal inversion-linked incompatability, Dumas et al. 2005) in a continuous geographical area, rather than being the result of allopatric speciation, as would be the case with $P$. baptista and P. hoffmannsi if the Paraná-Urariá River had acted as an effective geographical barrier. The occurrence of sympatric
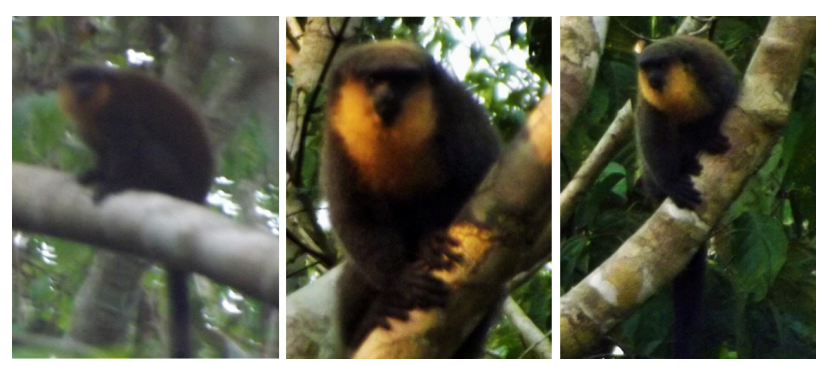

Figure 2. Images of a Plecturocebus baptista individual (left) and a potential $P$. hoffmannsi x P. baptista hybrid (centre and right) in Maués, Amazonas, Brazil.

Table1. Comparison of color attributes of Plecturocebus hoffmannsi and Plecturocebus baptista, following Gualda-Barros et al. (2012). Illustrations from Reis et al. (2015).

\begin{tabular}{lcc}
\hline & & \\
& P. hoffmannsii & P. baptista \\
\hline Body part & grayish agouti & blackish to grayish agouti \\
\hline Crown & grayish agouti & blackish to grayish agouti \\
\hline Forehead & yellowish & dark reddish brown \\
\hline Sideburns & grayish agouti & blackish to grayish agouti \\
\hline Dorsum & grayish agouti & blackish to grayish agouti \\
\hline Flanks & grayish agouti & dark reddish brown \\
Neck, chest and belly & grayish agouti & blackish to grayish agouti \\
\hline Hands and feet & grayish agouti & blackish to grayish agouti \\
\hline Limbs (outer) & yellowish & dark reddish brown \\
Limbs (inner) & dark grayish agouti & blackish to blackish agouti \\
\hline Tail & &
\end{tabular}

titi species also supports the dispersal model proposed for Cheracebus and Plecturocebus through sequential, long distance events involving jump dispersal across rivers (Byrne et al. 2018).

Overlap in the distribution of Plecturocebus species is rare. Vermeer et al. (2001) reported a case for $P$. discolor and $P$. oenanthe in Peru. Printes et al. (2018) also reported an overlap between P. baptista and $P$. hoffmannsi on the left bank of the Tapajós River. In our study area, overlap may have occurred either by active dispersal across a river (Link et al. 2015), or by passive translocation via meander cut-offs (Jackson and Austin 2013).

It is also important to recognise that some recorded evolutionary phenomena may be recent (Rull 2011). Consequently, rather than being a long-established zone of contact between taxa, ours may be an example of a bridgehead population, newly established and integrating with existing forms, with whom they may still form viable offspring (Lombaert et al. 2010). Future studies should (i) confirm the occurrence of P. baptista $\mathrm{x}$ ?. hoffmannsi hybrids in Maués, (ii) test whether they are fertile, (iii) determine the extent of the hybrid zone, and (iv) estimate the extent of genetic introgression, through non-invasive approaches such as satellite markers (Balloux et al. 2002) from fecal samples (Goossens et al. 2000). The areas where P. baptista is known to occur are subject to rapid habitat loss and fragmentation. Although titis are ecologically flexible and tolerant of human impacts (Chagas and Ferrari 2011), the speed and extent of habitat alteration should be cause for concern, specially since the species is not known to occur in any legally protected area. Within the municipality of Maués there are three protected areas in which the species could potentially occur (Maués State Forest, Pau-Rosa National Forest and Alto Maués Ecological Station), all connected to each other and with the Amanã National Forest, forming a conservation corridor with an area of 2,471,561 ha. Surveys and introgression studies of $P$. batista and $P$. hoffmannsi should be conducted in these areas.

Our observations extend the limit of the historical distribution of P. baptista (Roosmalen, 2002), and support the evidence of its sympatry with $P$. hoffmannsi recently reported by Printes et al. (2018). According to our data, Plecturocebus baptista traversed the Paraná-Urariá River and probably dispersed in the interfluve between the Amazonas (north), Madeira (southwest and west) and Tapajós (southeast and south) rivers to the left bank of the Tapajós (Printes et al. 2018). The interfluve was formerly considered the area occupied exclusively by $P$. hoffmannsi (Veiga 2008b), therefore, populations of $P$. baptista and $P$. hoffmannsi occur in sympatry in the area.

Primate population surveys in the wider area of the Tapajós-Madeira interfluve that aim to identify populations of Plecturocebus are necessary to understand the evolutionary history and ecology of the two species, as well as to ensure their preservation and that of their habitat. The dissemination of primological scientific knowledge is also key to promoting 
awareness and appreciation of local biodiversity, and integration with sustainable economic activities such as primate-based tourism (Marsh 2002).

\section{ACKNOWLEDGMENTS}

We would like to thank to Camilla Martins Botellho for their support and encouragement. We give special thank Dr. José de Souza e Silva Júnior for input wich improved the manuscript.

\section{REFERENCES}

Ayres, J.M.; Clutton-Brock, T.H. 1992. River boundaries and species range size in Amazonian primates. American Naturalist, 140: 531-537.

Balloux, F.; Lugon-Moulin, N. 2002. The estimation of population differentiation with microsatellite markers. Molecular Ecology, 11: 155-165.

Boubli, J.P.; Da Silva, M.N.; Rylands, A.B.; Nash, S.D.; Bertuol, F; Nunes, M.; et al. 2018. How many pygmy marmoset (Cebuella Gray, 1870) species are there? A taxonomic re-appraisal based on new molecular evidence. Molecular Phylogenetics and Evolution, 120: $170-182$.

Boubli, J.P.; Byrne, H.; da Silva, M.N.F.; Silva-Júnior, J.; Araújo, R.C.; Bertuol, F.; et al. 2019. On a new species of titi monkey (Primates: Plecturocebus Byrne et al., 2016), from Alta Floresta, southern Amazon, Brazil. Molecular Phylogenetics and Evolution, 132: 117-137.

Byrne, H.; Rylands, A.B.; Carneiro, J.C.; Alfaro, J.W.L.; Bertuol, F.; da Silva, M.N.; et al. 2016. Phylogenetic relationships of the New World titi monkeys (Callicebus): first appraisal of taxonomy based on molecular evidence. Frontiers in Zoology, 13: 10.

Byrne, H.; Lynch Alfaro, J.W.; Sampaio, I.; Farias, I.; Schneider, H.; Hrbek, T., et al. 2018. Phylogeny, molecular dating and zoogeographic history of the titi monkeys (Callicebus, Pitheciidae) of eastern Brazil. Molecular Phylogenetics and Evolution, 124: 10-15.

Chagas, R.R.D.; Ferrari, S.F. 2011. Population parameters of the endangered titi monkey, Callicebus coimbrai Kobayashi \& Langguth, 1999, in the fragmented landscape of southern Sergipe, Brazil. Brazilian Journal of Biology, 71: 569-575.

Dumas, F.; Bigoni, F.; Stone, G.; Sineo, L.; Stanyon, R. 2005. Mapping genomic rearrangements in titi monkeys by chromosome flow sorting and multidirectional in-situ hybridization. Chromosome Research, 13: 85-96.

Goossens B.; Chikhi, L.; Utami, S.S.; de Ruiter, J.; Bruford, M.W. 2000 A multi-sample, multi-extracts approach for microsatellite analysis of faecal samples in an arboreal ape. Conservation Genetics, 1: 157-162.

Gualda-Barros, J.; Nascimento, F.O.; Amaral, M.K. 2012. A new species of Callicebus Thomas, 1903 (Primates, Pitheciidae) from the states of Mato Grosso and Pará, Brazil. Papéis Avulsos de Zoologia, 52: 261-279.
Hershkovitz, P. 1990. Titis, New World monkeys of the genus Callicebus (Cebidae, Platyrrhini): a preliminary taxonomic review. Fieldiana: Zoology, 55: 1-109.

Jackson, N.D.; Austin, C.C. 2013. Testing the role of meander cutoff in promoting gene flow across a riverine barrier in ground skinks (Scincella lateralis). PLoS ONE, 8: e62812.

Link, A.; Valencia, L.M.; Céspedes, L.N.; Duque, L.D.; Cadena, C.D.; Di Fiore, A. 2015. Phylogeography of the critically endangered brown spider monkey (Ateles hybridus): Testing the riverine barrier hypothesis. International Journal of Primatology, 36: $530-547$.

Lombaert, E.; Guillemaud, T.; Cornuet, J.M.; Malausa, T.; Facon, B.; Estoup, A. 2010. Bridgehead effect in the worldwide invasion of the biocontrol harlequin ladybird. PLoS ONE, 5: e9743.

Marsh, L.K. 2002. A wonder lost or wander lust: tourists visit monkeys in the wild. Curator: The Museum Journal, 45: 199-212.

Printes, R.C.; Buss, G.; Azevedo, R.B.; Ravetta, A.L.; Silva, G.N. 2018. Update on the geographic distributions of two titi monkeys, Plecturocebus hoffmannsi (Thomas, 1908) and $P$. baptista (Lönnberg, 1939), in two protected areas in the Brazilian Amazon. Primate Conservation, 32: 81-88.

Reis, N.R.; Peracchi, A.L.; Batista, C.B.; Rosa, G.L.M. 2015. Primatas do Brasil (guia de campo). Technical Books, Rio de Janeiro, 328p.

Roosmalen, M.G.M.; Roosmalen, T.; Mittermeier, R.A. 2002. A taxonomic review of the titi monkeys, genus Callicebus Thomas, 1903, with the description of two new species, Callicebus bernhardi and Callicebus stephennashi, from Brazilian Amazonia. Neotropical Primates, 10: 1-52.

Rull, V. 2011. Neotropical biodiversity: timing and potential drivers. Trends in Ecology and Evolution, 26: 508-513.

Serrano-Villavicencio, J.E.; Vendramel, R.L.; Garbino, G.S.T. 2017. Species, subspecies, or color morphs? Reconsidering the taxonomy of Callicebus Thomas, 1903 in the Purus-Madeira interfluvium. Primates, 58: 159-167.

Veiga, L.M. 2008a. Plecturocebus baptista. The IUCN Red List of Threatened Species (http://www.iucnredlist.org/ details/41560/0). Accessed on 05 Aug 2018.

Veiga, L.M. 2008b. Plecturocebus hoffmannsi. The IUCN Red List of Threatened Species (http://www.iucnredlist.org/ details/41559/0). Accessed on 05 Aug 2018.

Vermeer, J.; Tello-Alvarado, J.C.; Moreno-Moreno, S.; GuerraVásquez, F. 2001. Extension of the geographical range of white-browed titi monkeys (Callicebus discolor) and evidence for sympatry with San Martín titi monkeys (Callicebus oenanthe). International Journal of Primatology, 32: 924-930.

RECEIVED: 06/01/2019

ACCEPTED: $14 / 05 / 2019$

ASSOCIATE EDITOR: Fernanda Michalski 